\title{
JORNALISMO E NARRATIVA TRANSMIDIÁTICA - DIÁLOGO ENTRE REPORTAGEM, CRÔNICA E CONTO
}

\author{
Carlos Pernisa Júnior ${ }^{1}$ \\ Marco Aurelio Reis ${ }^{2}$ \\ Claúdia de Albuquerque Thomé ${ }^{3}$
}

\section{Resumo}

Há cerca de um década, com a discussão de Henry Jenkins sobre narrativa transmidiática (2009), começou-se a se falar de jornalismo transmidiático mais intensamente, numa referência ao trabalho desse autor que se adaptaria ao cenário jornalístico. Os estudos neste sentido avançaram e foram feitas, desde então, tentativas de se produzir reportagens que se caracterizassem por trabalhar com essa abordagem em sua essência. Com o presente estudo epistemológico, pensa-se em tratar da questão sob o prisma não só da caracterização da narrativa transmidiática, mas também sob o ponto de vista literário, buscando verificar como a base narrativa pode apresentar possibilidades transmidiáticas. Leva-se em conta, também, as características da reportagem e de suas relações com a literatura, no chamado jornalismo literário.

Palavras-chave: Jornalismo. Narrativa Transmidiática. Crônica.

\section{JOURNALISM AND TRANSMIDIATIC NARRATIVE - DIALOGUE BETWEEN REPORTS, CHRONICLES AND TALE}

\begin{abstract}
About a decade ago, with the discussion of Henry Jenkins on transmedia narrative (2009), it started to talk about transmedia journalism more intensely, in reference to the work of this author who would adapt to the journalistic scenario. Studies in this direction have advanced and attempts have been made since then to produce reports that are characterized by working with this approach in its essence. With the present epistemological study, it is thought to address the issue from the perspective of not only the characterization of the transmedia narrative, but also from the literary point of view, seeking to verify how the narrative base can present transmedia possibilities. It also takes into account the characteristics of the report and its relations with literature, in what is called literary journalism.
\end{abstract}

\footnotetext{
${ }^{1}$ Universidade Federal de Juiz de Fora (UFJF), Juiz de Fora - Minas Gerais - Brasil. Doutor em Comunicação e Cultura pela Universidade Federal do Rio de Janeiro. Professor titular da Universidade Federal de Juiz de Fora e membro do corpo permanente do Programa de Pós-Graduação em Comunicação da mesma instituição. ORCID $<$ https://orcid.org/0000-0002-5003-0094>.E-mail: carlos.pernisa@ufjf.edu.br.

${ }^{2}$ Universidade Estácio de Sá, Rio de Janeiro - Brasil. Doutor em Ciência da Literatura pela UFRJ. Professor do curso de Jornalismo e pesquisador bolsista do Programa de Pesquisa e Produtividade da Universidade Estácio de Sá (RJ), líder do Grupo de Pesquisa Narrativas Midiáticas e Dialogias (UFJF/Unesa-RJ). ORCID $<$ https://orcid.org/0000-0003-0710-6361>. E-mail: mreis1968@gmail.com.

${ }^{3}$ Universidade Federal de Juiz de Fora (UFJF), Juiz de Fora - Minas Gerais - Brasil. Doutora em Ciência da Literatura (Teoria Literária) pela Faculdade de Letras da UFRJ. Professora da Faculdade de Comunicação da Universidade Federal de Juiz de Fora (Facom-UFJF) e do Programa de Pós-graduação em Comunicação da UFJF, é líder do Grupo de Pesquisa/CNPq Narrativas midiáticas e dialogias, integra a Rede de Pesquisadores de Telejornalismo (Rede Telejor) e é membro do Grupo de Pesquisa/CNPq Estéticas de Fim de Século, da UFRJ. ORCID <https://orcid.org/0000-0003-4759-3643 >. E-mail: cthomereis@gmail.com.
} 


\section{Linguagens - Revista de Letras, Artes e Comunicação - ISSN 1981-9943 \\ Blumenau, v. 14, n. 1, p. 093-111, jan./abr. 2020 \\ DOI: http://dx.doi.org/10.7867/1981-9943.2020v14n1p093-11}

Keywords: Journalism. Transmediatic Narrative. Chronicle.

\section{INTRODUÇÃO}

Em 2006, o professor da universidade do Sul da Califórnia Henry Jenkins publica, nos Estados Unidos, Cultura da convergência e dedica um capítulo - "Em busca do unicórnio de origami: Matrix e a narrativa transmídia" - ao estudo do que ele chama de narrativa transmidiática ou transmídia ${ }^{4}$. Por narrativa transmídia, Jenkins entende que deve ser pensada em múltiplas plataformas, sendo que cada narração contribua de maneira distinta para o todo narrado. Diz ele ser necessário que cada meio tenha seus recursos explorados ao máximo, sendo autônomo de modo que seu consumo isolado não atrapalhe a compreensão e o consumo do todo garanta uma experiência diferente por sua profundidade que induza a mais consumo (JENKINS, 2009, p.138).

Assim, o pesquisador estadunidense define, em linhas gerais, o que seria sua compreensão de narrativa transmidiática, buscando caracterizar alguns pontos que ele julga mais importantes, como o fato de haver um conjunto de histórias que se conectam, mas não são dependentes umas das outras, formando um universo narrativo; a utilização de diversas plataformas de mídia para a sua organização; e a possibilidade de múltiplas entradas nesse universo, sem que haja necessariamente um primeiro ponto de acesso. Esses dados são importantes para caracterizar a ideia geral proposta por Jenkins e fazer com que a narrativa transmidiática possa ser entendida e explorada também em áreas que vão além do entretenimento.

Há que se fazer uma ressalva. Jenkins trata, em muitos de seus textos, de uma relação mercadológica com a cultura. Daí a utilização de termos como franquia e consumidor, entre outros. Isso faz com que alguns pensem que seus escritos só interessariam a áreas de marketing e publicidade, entre outras. Na verdade, podem haver outras entradas, desde que se faça essa ressalva e que se utilizem outras ferramentas para a análise do que ele propõe como defendem Dall'agnese e Barichello (2018).

Dito isso, busca-se em fazer aqui uma relação entre a narrativa transmidiática, tal como Jenkins a caracteriza, com o jornalismo contemporâneo. Busca-se ainda, nessa perspectiva, detectar como o dito jornalismo midiatizado (SOSTER, 2013), que tem como

\footnotetext{
${ }^{4}$ A primeira edição brasileira, da Aleph, de 2008, traz o termo narrativa transmidiática, já a edição ampliada e atualizada de 2009 usa o termo transmídia.
} 


\section{Linguagens - Revista de Letras, Artes e Comunicação - ISSN 1981-9943 \\ Blumenau, v. 14, n. 1, p. 093-111, jan./abr. 2020 \\ DOI: http://dx.doi.org/10.7867/1981-9943.2020v14n1p093-11}

uma de suas características a dialogia, "oferece novos níveis de revelação", nos termos de Jenkins, cada vez que se entrelaça com outros campos, em torno de um mesmo gancho temático. É o caso da crônica que, ancorada no mesmo agendamento temático, é veiculada nos diferentes meios de comunicação trazendo conteúdos e aspectos nem sempre previstos na cobertura jornalística, mas que acrescentam novos níveis de entendimento ou aspectos que não cabem na reportagem. Esta relação entre jornalismo e literatura não é nova, mas o potencial de entrelaçamento entre os dois campos se acelera no ambiente midiático atual, marcado por novas configurações de linguagem, tanto no jornal e no webjornalismo, quanto no radiojornalismo e no telejornalismo.

\section{GÊNEROS LITERÁRIOS E JORNALISMO MIDIATIZADO}

O diálogo entre o jornalismo e a literatura é bem anterior ao contexto de narrativas transmidiáticas. Como afirma Figueiredo (2010, p. 12), tais interseções entre campos culturais não são fenômenos novos, "embora tenham chegado ao paroxismo com as tecnologias digitais". São perceptíveis os pontos de convergência entre os dois campos desde o século XIX, com a publicação de capítulos de romances nos jornais, na forma de folhetins (MEYER, 1996). Este cruzamento não apaga as especificidades dos dois campos, mas deixa marcas na produção das narrativas que precisam ser adaptadas para cada suporte.

O entrelaçamento entre a prosa literária e a reportagem está na origem das convenções de representação que caracterizam o romance realista, do mesmo modo que a proximidade com a nascente cultura periodística abre caminho para o surgimento do conto policial e da crônica moderna. (FIGUEIREDO, 2010, p. 12).

O que é notável no atual contexto é a aceleração desse processo de cruzamento entre narrativas jornalísticas e literárias, com o incremento das possibilidades de criação e de distribuição de narrativas, no cenário de convergência midiática e as novas configurações de consumo do noticiário no chamado narrowcasting. (VAN DIJCK, 2013; JENKINS 2009).

O presente trabalho busca entender este processo do ponto de vista do jornalismo, em como outros gêneros textuais dialogam com a reportagem e com uma produção de conteúdo que se completa em diversas narrativas pela rede, do noticiário à história contada, com personagens que vivem um cotidiano dito "real" ou que refletem a imaginação do cronista e do contista a partir de situações vividas. Nesta perspectiva, vale dizer que o jornalismo midiatizado, conceituado por Soster (2013), tem como uma de suas características a dialogia: 


\section{Linguagens - Revista de Letras, Artes e Comunicação - ISSN 1981-9943 \\ Blumenau, v. 14, n. 1, p. 093-111, jan./abr. 2020 \\ DOI: http://dx.doi.org/10.7867/1981-9943.2020v14n1p093-11}

[...] diz respeito ao que resulta do acoplamento estrutural entre dois sistemas, provocando transformações em um e outro. É quando o jornalismo vai buscar na literatura subsídios para estabelecer diferenças, reconfigurando-se nas instâncias de emissão, recepção, circulação e reconhecimento, ou quando, dialogicamente, a literatura passa a se valer de lógicas comunicacionais para dar conta de seus processos. (SOSTER, 2013, p.13).

O entrelaçamento entre os campos, no entanto, não representa uma unificação em suas especificidades e seus objetivos, mas acelera-se no contexto do jornalismo midiatizado, de forma complementar, oferecendo a seu público novas camadas de conteúdo em torno da temática que originou a narrativa central em processo com potencial transmidiático. E é este fenômeno que chama a atenção da presente pesquisa, demandando, portanto, uma definição das diferentes tipologias aqui tratadas.

A reportagem é o que Muniz Sodré e Maria Helena Ferrari chamam de "o lugar por excelência da narração jornalística [...] separada, entretanto, da literatura por seu compromisso com a objetividade informativa" (SODRÉ; FERRARI, 1986, p. 9). Desse modo, é possível destacá-la como o elemento fundamental para este estudo, já que está se tratando aqui de narração, de histórias sendo contadas e não de descrições ou argumentações e não se coloca também a notícia, como a informação curta e imediata, como horizonte de pesquisa. Esta última não serviria como parâmetro pela concepção de jornalismo, segundo outro olhar do professor Muniz Sodré sobre o tema:

Apelando-se para uma metáfora técnica, comparativa dos gêneros, é possível aceitar que a notícia seja uma fotografia do acontecimento; a reportagem, um pequeno filme, e a crônica, um caleidoscópio, ou seja, a possibilidade de uma visão multifacetada do cotidiano [...]. (SODRÉ, 2009, p. 145).

As notícias diárias atendem a certas configurações que são mais imediatistas e que não se preocupam tanto com expansões ou conexões, diferentemente das reportagens, sobretudo as dominicais, que têm em vista justamente maior aprofundamento do fato ou da história e de seus personagens, sem perder o viés jornalístico, mas se aproximando, por vezes, da literatura. "No jornalismo - tanto no chamado livro-reportagem, quanto no jornal diário - a reportagem amplia a cobertura de um fato, assunto ou personalidade, revestindo-os de intensidade, sem a brevidade da forma-notícia” (SODRÉ; FERRARI, 1986, p. 75).

Partindo daí, é possível entender que a reportagem seria a base da narrativa transmidiática jornalística, por se configurar como "um gênero transversal a todas as mídias" (CANAVILHAS, 2014, p. 64). O problema seguinte é como se produzir material nesse estilo. 


\section{Linguagens - Revista de Letras, Artes e Comunicação - ISSN 1981-9943 \\ Blumenau, v. 14, n. 1, p. 093-111, jan./abr. 2020 \\ DOI: http://dx.doi.org/10.7867/1981-9943.2020v14n1p093-11}

Se o parâmetro for o próprio texto de Jenkins, a narrativa jornalística transmidiática deveria ter alguns pontos básicos, tais como: histórias autônomas que se conectam, sem que nenhuma seja mais importante que as outras e nem que haja a necessidade de entrada por uma delas especificamente. Outro aspecto seria que essas histórias estariam disponíveis em diferentes plataformas ou meios ${ }^{5}$ para que cada uma delas pudesse usar o que tem de melhor para que cada história seja contada.

Uma dúvida a ser levantada é a da formação de um universo narrativo particular próprio do jornalismo transmidiático. Nesse caso, Motta (2013) aponta que o material jornalístico deve ser visto como narrativas se forem colocadas as matérias em relação umas com as outras, formando um desenrolar da história, o chamado plano da estória. Assim, seria possível pensar na formação de algo que, mesmo que não seja um universo, torna-se um contexto comum para que a narrativa se desenvolva.

A contextualização é uma das características apontadas por Canavilhas (2014) como fundamentais para que se possa configurar o jornalismo transmídia, assim como a interatividade, a hipertextualidade e a multimedialidade integrada. Tais pontos levam a pensar em um modelo-base que possa dar conta da gênesis do jornalismo transmidiático.

É importante considerar, no entanto, que tais características apontam para possibilidades na construção narrativa, tanto na emissão quanto na recepção. Uma razão é clara para isso: cada história transmidiática é construída quase que de forma única, adaptandose a uma série de fatores que vão ser as bases para a construção de um todo narrativo. A história não é contada a partir de uma construção prévia, mas sim do contato com possíveis modos de organização, que também se inscrevem como transitórios e não determinantes do conteúdo a ser veiculado.

Como dito anteriormente, a narrativa vai se fazendo por conexões entre diversos meios ou plataformas. No caso jornalístico, pode-se pensar em reportagens que estejam em veículos os mais variados, sem que se tenha feito, previamente, uma relação entre eles. Para Denis Renó e Luciana Renó (2013, p. 57), em livro organizado por Canavilhas (2013), a narrativa transmídia demanda uma preparação dos jornalistas para esse novo cenário.

O jornalismo transmídia é uma forma de linguagem jornalística que contempla ao mesmo tempo distintos meios com várias linguagens e narrativas a partir de

\footnotetext{
${ }^{5}$ Neste caso, fala-se aqui em plataformas multimidiáticas porque acredita-se que haja a possibilidade, cada vez maior, de se ter uma narrativa transmídia só no âmbito da Internet, por exemplo, utilizando-se, para isso, de plataformas diferentes e não necessariamente de meios diversos em outros ambientes, o que não quer dizer que isso não possa ser feito também.
} 


\section{Linguagens - Revista de Letras, Artes e Comunicação - ISSN 1981-9943 \\ Blumenau, v. 14, n. 1, p. 093-111, jan./abr. 2020 \\ DOI: http://dx.doi.org/10.7867/1981-9943.2020v14n1p093-11}

inúmeros meios e para uma infinidade de usuários. Para tanto, devem ser adotados recursos audiovisuais, de comunicação móvel e de interatividade na difusão do conteúdo, inclusive a partir da blogosfera e das redes sociais, o que amplia de forma considerável a circulação do conteúdo. (RENÓ, RENÓ, 2013, p. 62).

A produção de conteúdo transmidiático demanda também estratégias narrativas afinadas com o atual contexto midiático, caracterizado pelo que Piccinin e Soster (2012) definem como jornalismo midiatizado. Além da dialogia, os autores apontam outra característica importante para o presente estudo: a descentralização das mídias, em uma lógica rizomática. Assim, o conteúdo é distribuído em fluxo, sem uma hierarquia entre as mídias, o que, como dito anteriormente, precisa também ser levado em conta ao se pensar em jornalismo transmídia.

Nesse cenário, intensifica-se o entrelaçamento de gêneros jornalísticos, que passam a coexistir na web, como detecta Marques de Melo (2012).

Diante desse panorama surpreendente, deparamo-nos com um fenômeno singular: a coexistência de todas essas modalidades de expressão jornalística numa plataforma midiática convergente: a internet. Por isso mesmo, alguns estudiosos anteveem uma espécie de "hibridismo", por meio da fusão de gêneros, enquanto outros, mais pessimistas, predicam até mesmo o "fim do jornalismo". (MARQUES DE MELO, 2012, p. 25).

No hibridismo dos gêneros, o jornalismo transmidiático pode carregar conteúdos informativos e também outros, próprios do gênero diversional, seguindo as classificações de Marques de Melo (2012), assim como do jornalismo opinativo, em que a crônica aparece como formato (MARQUES DE MELO, ASSIS, 2016). E tais conteúdos estariam disponibilizados na web de forma complementar a partir da busca temática tagueada (REIS, 2018). Assim, pode ser tanto mais ligado ao entretenimento e, por consequência, à literatura, quanto ao jornalismo. Isso vai depender dos meios usados e das intenções de quem produz.

Se o entretenimento aparece como característica principal e a narrativa tem mais ligação com a ficção e com o viés literário, há um distanciamento do caráter estritamente informativo e uma aproximação com o diversional.

Por outro lado, pode-se pensar em um modo diverso de organização, no qual a informação tem relevância e o material produzido tem caráter mais documental. Isso é importante para dizer que existem nuances a serem consideradas e que uma narrativa transmidiática pode carregar traços jornalísticos e literários ao mesmo tempo, evidenciando na 


\section{Linguagens - Revista de Letras, Artes e Comunicação - ISSN 1981-9943 \\ Blumenau, v. 14, n. 1, p. 093-111, jan./abr. 2020 \\ DOI: http://dx.doi.org/10.7867/1981-9943.2020v14n1p093-11}

web a tendência a uma hibridização dos gêneros jornalísticos - informativo, opinativo, interpretativo, utilitário e diversional, seguindo a classificação de Marques de Melo (2012).

\section{CONTO E CRÔNICA - GÊNEROS TEXTUAIS COM POTENCIAL PARA TRANSMÍDIA}

Como gêneros literários, conto e crônica dialogam com o jornalismo desde os primórdios da massificação da imprensa. Tal relação leva em conta certos aspectos que devem ser destacados. Um deles é o uso de histórias intertextuais (GENETTE, 1982) na forma de contos ou de crônicas que se ligam entre si. Uma relação com imenso potencial transmidiático.

Como isso se dá?

A proposta é verificar que o conto ou a crônica, quando em forma de reportagem, podem perfeitamente ser histórias independentes que se conectam. Tal conexão literáriojornalística fica certamente mais clara quando se observa uma estrutura maior, como a do romance-reportagem, por exemplo. No entanto, quando o objeto a ser analisado é um conjunto de contos ou crônicas é necessário um esforço leitor para fazer possíveis ligações links - entre essas narrativas. Cabo, portanto, observar tais gêneros mais de perto.

$\mathrm{O}$ conto é de difícil definição. O poeta e crítico literário Mário de Andrade (apud SODRÉ; FERRARI, 1986, p. 86) disse certa vez que "conto é tudo aquilo que chamamos de conto". E Sodré e Ferrari acrescentam que o mesmo se pode dizer da crônica. O que é indicado por eles é que conto geralmente é uma história curta que "apresenta uma centelha, um momento, uma fatia temporal da existência de um personagem" (SODRÉ; FERRARI, 1986, p. 75). Já a crônica apresenta um narrador em "posição observadora ou reflexiva (é raro que se intrometa, por exemplo, em pensamentos de personagens)" (SODRÉ; FERRARI, 1986, p. 86), sendo uma narrativa, por vezes, mais curta que o conto.

Desse modo, conto ou crônica servem à ideia de transmídia no sentido de serem construídos como histórias únicas, mas que podem ser conectadas de diversas formas. Tais gêneros configuram, portanto, uma gênesis ainda pouco explorada nos estudos sobre jornalismo transmidiático.

Um exemplo: o autor e crítico literário argentino Jorge Luis Borges publicou uma série de pequenas histórias em que falava sobre labirintos. Essas histórias não saíram em um 


\section{Linguagens - Revista de Letras, Artes e Comunicação - ISSN 1981-9943 \\ Blumenau, v. 14, n. 1, p. 093-111, jan./abr. 2020 \\ DOI: http://dx.doi.org/10.7867/1981-9943.2020v14n1p093-11}

único volume e não são, necessariamente, dependentes umas das outras, mas uma possibilidade latente é se fazer uma conexão entre elas, tendo o labirinto como referência.

Assim, há que se perceber que o mesmo pode valer para reportagens em que a estrutura lembra o conto ou a crônica, ora desenvolvendo uma única história e tendo apenas um clímax e ora namorando com o simples cotidiano em narrativa enxuta com a rapidez de um flash. No caso, seria possível pensar em reportagens-conto ou reportagens-crônica, quando se tratar de observar material com características claramente jornalísticas, seguindo as definições de Sodré e Ferrari (1986).

A partir dos autores, pode-se pensar na reportagem-conto como aquela que particulariza a ação, escolhendo um personagem central para ilustrar o tema a ser desenvolvido e que atua durante toda a narrativa (SODRÉ, FERRARI, 1986, p. 77 e 81) centrada em um acontecimento central condutor. Difere-se aqui, cabe destacar, reportagemconto, que tem o jornalismo com preocupação central, do chamado conto-reportagem (FURHMANN, 2008; LOPES, 2018), no qual o jornalismo é objeto de inspiração e a centralidade está no modo de narrar que pode ancorar-se no ficcional.

Já a reportagem-crônica trata de flagrantes do cotidiano ou situações fortuitas, com o narrador tomando uma posição observadora ou reflexiva (SODRÉ, FERRARI, 1986, p. 86). Próximo ao leitor, conquista pela linguagem e simplicidade na chamada narrativa "ao rés do chão" (CANDIDO, 1980).

Ambas tipologias de reportagens podem ser publicadas de modo independente ou relacionadas e também em meios diversos, sem que haja prejuízo em cada uma dessas formas. A ideia de se ter conexões entre elas pode trazer um maior aprofundamento, criando para aquele que assume a posição de receptor uma maneira diferenciada de perceber o todo, um leitor real ou empírico nos termos de Iser (1996), sendo aquele que percorre a narrativa em busca de absorver o discurso.

Nesta perspectiva, propõe-se, como exemplo temático, a recorrente pauta jornalística sobre a violência na cidade do Rio de Janeiro. Além de todo noticiário com sequência de mortes nas páginas dos jornais e nas escaladas dos telejornais, uma busca na rede traz ainda conteúdos produzidos anteriormente e muitos até hoje presentes e atuais nos veículos de comunicação, que trazem complementaridade ao quadro exposto, não apenas em dados, mas em experiência, em sentimentos. Assim, pode-se pensar, no atual contexto midiático, em uma complementariedade entre as narrativas em torno de uma temática, podendo isso acontecer em meios e em veículos de comunicação diferentes. 


\section{Linguagens - Revista de Letras, Artes e Comunicação - ISSN 1981-9943 \\ Blumenau, v. 14, n. 1, p. 093-111, jan./abr. 2020 \\ DOI: http://dx.doi.org/10.7867/1981-9943.2020v14n1p093-11}

Considerando as especificidades de cada gênero textual e/ou de cada formato audiovisual, observa-se na crônica a possibilidade de diálogo com esse noticiário amplificado, algo relevante para formação de um jornalismo transmidiático, ancorado em material fático. É preciso lembrar que a crônica pode se apresentar em diferentes tipos, seguindo classificações do teórico Afrânio Coutinho (1971), segundo as quais a crônica ancorada no noticiário tem potencial para trazer a determinadas coberturas jornalísticas o aspecto humanizado ou o detalhe que nem sempre cabe na cobertura factual, mas que chama a atenção do cronista.

A crônica televisual do jornalista Pedro Bial, na edição do Fantástico (Rede Globo) do dia 24/09/2017, por exemplo, configura essa narrativa que oferece novos níveis de revelação e experiência a um cotidiano que já vinha sendo noticiado. Trata do medo, de um sentimento diante da triste e longa história da violência no Rio.

\footnotetext{
Demorou... Por um dia, o carioca, esse brasileiro na vitrine, pôde esquecer todos os seus medos: medo do estado quebrado e seu salário atrasado, medo do desemprego, medo de não saber quem é bandido e quem é autoridade, medo da eleição ano que vem, medo do ano que vem, medo do futuro - pudemos esquecer todos esses medos, pois um medo muito maior e imediato tomou conta de tudo. Um medo instantâneo $\mathrm{e}$ insolúvel, o medo de sair de casa, agora, medo do presente instante. (BIAL, 2017).
}

Essa crônica foi distribuída como narrativa multimídia - na TV e no site, em vídeo e em texto, e nas redes sociais -, e nas redes e site gerou comentários no espaço de interatividade, sendo alguns abordando assuntos afins, mas não diretamente relacionados com o texto postado e outros reproduzindo em texto a narrativa televisual. Na reprodução nas redes sociais, identifica-se a permanência da reflexão em outra temporalidade, dois anos mais tarde, em compartilhamento de internauta a partir de campanha pela paz no Rio.

Figura 1. Reflexão da TV incorporada ao \#riopedesocorro das redes sociais

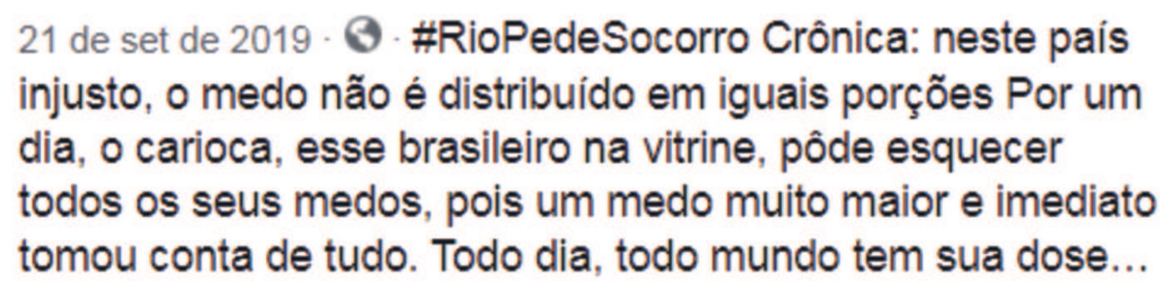
injusto, o medo não é distribuído em iguais porções Por um dia, o carioca, esse brasileiro na vitrine, pôde esquecer todos os seus medos, pois um medo muito maior e imediato tomou conta de tudo. Todo dia, todo mundo tem sua dose...

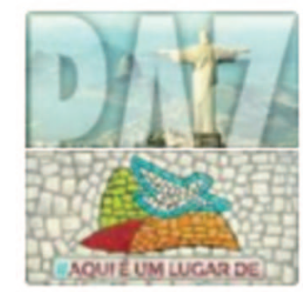




\section{Linguagens - Revista de Letras, Artes e Comunicação - ISSN 1981-9943 \\ Blumenau, v. 14, n. 1, p. 093-111, jan./abr. 2020 \\ DOI: http://dx.doi.org/10.7867/1981-9943.2020v14n1p093-11}

Observando tal exemplo, nota-se o potencial da crônica quando integrada a uma rede de conteúdos. Acessada a partir da busca do webleitor e do interesse por determinada temática, ela se insere em um conjunto que não obrigatoriamente fez parte da intenção inicial dos produtores. A crônica, portanto, como gênero textual que se propõe a oferecer o que não cabe no noticiário, traz carga subjetiva, o sentimento, tendo, portanto, potencial de complementar de forma humanizada a reportagem jornalística, sobretudo nas temáticas sobre morte e tragédias, alongando sua fruição ao longo do tempo, como no exemplo acima.

Em termos de literatura, pode-se dizer que a experiência de fruição de uma obra também não vai ser a mesma para todos os leitores e que há algo que sempre vai além do que está escrito no texto, algo que escapa e está na ordem da produção de sentido por parte do leitor.

Tal fruição particular também pode aparecer nas reportagens, sobretudo as com viés literário, independente se o modelo é o do conto ou o da crônica. Assim, destaca-se que a narrativa jornalística, com sua tentativa de maior objetividade, não é a única meta prevista por quem faz esse tipo de jornalismo. Essa caraterística deve ser observada numa análise que leve em conta o modelo transmidiático de publicação.

Como pensar o conto e a crônica como participantes da narrativa transmidiática? Esse é um ponto a ser analisado com cautela. Nem todo conto ou crônica tem necessariamente uma tendência a ser transmídia ou, ao menos, conteúdo essencialmente informativo jornalístico. Como tais textos são geralmente autônomos, o grau de autonomia pode levar a histórias totalmente independentes e que não necessitem nenhum aprofundamento inicial.

Ocorre, porém, que diante da amplitude narrativa e do potencial interpretativo do receptor, percepções pessoais de sentido podem levar a um aprofundamento imensurável, escondendo, portanto, um poder amplificado na era da cultura digital. Passa-se, então, a tratar do jornalismo em sua aproximação com a literatura e suas configurações nas reportagensconto e crônica.

A ideia de jornalismo literário é antiga, com destaque para o que se chama de new journalism nos Estados Unidos em meados do século passado. Essa aproximação entre jornalismo e literatura reconfigurou a maneira de se pensar e fazer jornalismo a partir de então. No Brasil, alguns anos depois desse movimento, surgiram alguns exemplos de reportagens, principalmente em revistas, que também faziam o mesmo tipo de relação. Ainda que os repórteres da revista Realidade digam que não se inspiraram no modelo vindo dos EUA (RIBEIRO; MARÃO, 2010, p. 31-2), há semelhança entre o que foi feito lá e o que foi desenvolvido aqui, em seguida, principalmente em relação ao texto mais livre, menos 


\section{Linguagens - Revista de Letras, Artes e Comunicação - ISSN 1981-9943 \\ Blumenau, v. 14, n. 1, p. 093-111, jan./abr. 2020 \\ DOI: http://dx.doi.org/10.7867/1981-9943.2020v14n1p093-11}

dependente de uma fórmula de escrita, que daria luz ao chamado romance-reportagem dos anos 70 no Brasil. (COSSON, 2001).

No curso dessa aproximação, deve-se levar em conta que o jornalismo também tem características de formas literárias. Muniz Sodré e Maria Helena Ferrari dizem que conto e reportagem "se assemelham: pode-se dizer que a reportagem é o conto jornalístico" (SODRÉ; FERRARI, 1986, p. 75). Motta (2013) já coloca que:

\footnotetext{
No jornalismo, a narrativa se configura muitas vezes em uma única reportagem ou em uma notícia tipo fait divers (notícias de interesse humano, relatos de dramas e tragédias pessoais, fatos insólitos, lugares pitorescos), cuja estrutura fechada se assemelha à do conto (...). Nesse gênero de reportagem, tipo soft news, o jornal e seus editores concedem ao repórter uma liberdade maior para criar, relatar e contar em uma linguagem quase literária ou quase ficcional. O repórter se desvencilha então dos rigores da linguagem enxuta e objetivada, do compromisso de se manter próximo ao referente empírico, e ganha liberdade para imaginar, criar e sugerir no texto efeitos estéticos de sentido. (MOTTA, 2013, p. 95).
}

Motta também observa:

O texto desse gênero de reportagem afasta-se do jornalismo duro do dia a dia, adquire maior dramaticidade, uma estrutura semelhante à do conto, e pode ser estudado conforme qualquer outra narrativa de ficção, porque sua intenção é menos produzir efeitos de veracidade que efeitos estéticos próprios da ficção. (MOTTA, 2013, p. 33).

Preocupado com esses efeitos estéticos da ficção estava Borges, que trabalhou basicamente com poemas e contos, além dos ensaios. O autor argentino não era romancista, mas dedicava-se aos contos, nos quais acreditava haver mais espaço para ações representativas se darem de maneira mais intensa, ao contrário do romance que se utiliza de espaços vazios de intensidade, ligando os pontos mais importantes da trama. O escritor percebe que o foco de interesse do que está sendo contado é o aspecto fundamental numa narrativa e passa a usar essa percepção no desenvolvimento dos seus contos.

Borges não fica preocupado em contar uma grande história feita de várias tramas que se completam. Ele simplesmente conta estas várias histórias em forma de pequenos textos quase sempre contos e poemas - e faz com que seu leitor perceba os pontos de maior interesse quando ele se dedica a descrever - e escrever - suas cenas. Nota-se, então, que Borges não deixa de escrever, de certa forma, como os romancistas, mas o faz em outra escala. Seus personagens ou focos de interesse - tigres, labirintos, obras literárias, por exemplo - 


\section{Linguagens - Revista de Letras, Artes e Comunicação - ISSN 1981-9943 \\ Blumenau, v. 14, n. 1, p. 093-111, jan./abr. 2020 \\ DOI: http://dx.doi.org/10.7867/1981-9943.2020v14n1p093-11}

ressurgem em diversos de seus contos, criando uma rede que se engendra de outra forma, que não a leitura linear de seus livros em processo transtextual (GENETTE, 1982).

Aqui pensa-se, então, na gênesis da contemporânea forma de se consumir narrativas jornalísticas, literárias e audiovisuais, marcadas, como dito anteriormente, pelo consumo narrowcasting. E também pode-se pensar na questão da transmídia.

Ainda que que não se possa falar, a priori, de construção intencional de uma obra transmidiática, o que se tem é uma organização em que determinados assuntos ou personagens podem estar em foco em vários textos; como o conjunto de contos de Borges, publicados em vários livros diferentes e também em anos distintos, pode ser estudado sob este aspecto (PERNISA JÚNIOR, 2010). Numa possibilidade de se pensar em estruturas independentes que se relacionam, pode-se verificar unidades temáticas figurando nessas diversas obras e particularmente nos contos do autor.

Seria possível ler seus contos numa outra ordem, buscando, em determinado caso, as referências que ele faz a tigres em vários de seus escritos. Não existe o livro "Os tigres de Borges", mas não seria difícil produzi-lo a partir de uma estrutura em que todos os textos dele que contivessem menções a tigres estivessem disponíveis para um possível leitor. Além disso, pode-se pensar em um modelo hipertextual, em que um destes tigres aparecesse em um determinado conto e pudesse ser relacionado a outros tigres de forma aleatória dentro da obra geral de Borges, o que faria com que cada leitor tivesse novas possibilidades de leitura e não a mesma. Além disso, outros termos que fossem de especial interesse para Borges poderiam fazer parte da rede hipertextual. Assim, seria possível começar a ler sobre os tigres, mas continuar a leitura pelas Mil e Uma Noites, chegando, por fim, aos labirintos. (PERNISA JÚNIOR, 2010).

Essa construção, ainda que diga respeito somente à literatura e não seja transmídia em essência, já que o meio é sempre o do livro impresso, dá a ideia geral do que se pretende aqui. Não se trata somente de ver pela perspectiva do jornalismo, mas de perceber pontos em comum entre jornalismo e literatura. E, mais ainda, de perceber estruturas que podem levar a uma construção transmidiática a partir de uma gênesis textual. Neste sentido, a criação desse tipo de estrutura auxilia na possibilidade de antever possibilidades de narrativas jornalísticas transmidiáticas, já que o jornalismo não está apartado desta discussão. Algo que se configura com o telejornal que remete ao jornal e ao podcast, e esses três a sites e redes sociais e estas como compartilhamento de telereportagens, podcasts e conteúdo jornalístico impresso. Além desse processo multimidiático, pode-se perceber produtos conteudísticos em cada uma das mídias - impressa, sonora e visual - que se complementam para contar uma mesma história. 


\title{
Linguagens - Revista de Letras, Artes e Comunicação - ISSN 1981-9943 \\ Blumenau, v. 14, n. 1, p. 093-111, jan./abr. 2020 \\ DOI: http://dx.doi.org/10.7867/1981-9943.2020v14n1p093-11
}

\section{CRONISMO NA TV E NA WEB - PERSPECTIVAS PARA A NARRATIVA TRANSMÍDIA}

Potencial semelhante ao conto tem a crônica no tocante à aproximação com o jornalismo. Afinal, no Brasil, a crônica nasce nas páginas do jornal impresso e desliza pelos diferentes meios de comunicação, em um processo de mutação e de diálogo com as temáticas de cada época.

\begin{abstract}
A crônica nasce no jornal impresso, faz sucesso nas ondas do rádio e chega à televisão e à Internet. O gênero está na fronteira entre jornalismo e literatura desde seu nascimento, e flana pelos diversos meios de comunicação há décadas. Portanto, trata-se de uma narrativa que carrega em si um potencial híbrido, mutante, que se adapta e se molda para caber entre as linhas da página impressa, nos minutos de oralidade no programa de rádio ou no espelho de um telejornal. E na web encontra espaço em todos esses formatos, podendo ser acessada a qualquer momento, sem a limitação da grade de programação, do tempo no rádio ou das colunas dos jornais impressos. (REIS; THOMÉ, 2017, p. 565).
\end{abstract}

A crônica está presente em várias manifestações jornalísticas e em vários veículos. Alguns exemplos vêm dos jornais, como o Jornal do Brasil, que publicava textos de Carlos Drummond de Andrade e Carlos Eduardo Novaes, para citar apenas esses dois. Na televisão, ainda contemporaneamente, o Jornal Hoje, da TV Globo, traz aos sábados suas crônicas feitas por repórteres que são correspondentes em países da América, da Europa e da Ásia.

Foi natural, portanto, que consolidado nas páginas dos jornais, o cronismo brasileiro conquistasse outros meios de comunicação de acordo com seu surgimento e popularização no país. Assim, na forma própria brasileira, a crônica ganhou espaço nas ondas do rádio e, posteriormente, na tela da televisão. Mais recentemente, crônicas conquistaram leitores (os chamados pageviews) de sites e blogs da Internet. (REIS, 2015, p.43).

É preciso considerar que as crônicas, bem como também os diferentes gêneros jornalísticos, foram atravessadas também por mudanças no novo contexto comunicacional, no cenário de convergência, passando por mutações tanto no seu modo de produção como de distribuição. Pesquisa realizada pelo grupo "Narrativas Midiáticas e Dialogias" sobre o cronismo audiovisual detectou marcas da virtualidade na construção narrativa do "J10 em crônica”, quadro do Jornal das Dez, da Globonews, que apresenta temáticas internacionais já noticiadas a partir de um olhar mais humanizado, mas que dialoga com reportagens da 


\title{
Linguagens - Revista de Letras, Artes e Comunicação - ISSN 1981-9943 \\ Blumenau, v. 14, n. 1, p. 093-111, jan./abr. 2020 \\ DOI: http://dx.doi.org/10.7867/1981-9943.2020v14n1p093-11
}

semana. As crônicas, veiculadas na TV e disponibilizadas no portal da Globonews, (re)criam o cotidiano em espaços narrativos sem fronteiras.

Tais crônicas são unidades autônomas, sendo entendidas e sentidas sem a necessidade de fruição de outros conteúdos, e oferecem o que Jenkins aponta como característica da narrativa transmidiática: "novos níveis de revelação e experiência", o que pode ser observado no "J10 em crônica":

\begin{abstract}
O potencial formador de opinião aparece a cada momento, sem adjetivações, mas a cada sobe som no cenário de guerra ou no choro silencioso do pai que perdeu os filhos. Também de Guga Chacra, a crônica "Imagem de gêmeos mortos em ataque químico na Síria chocou o mundo”, exibida em 8/04/2017, aproxima Alemanha e Estados Unidos e afirma: "Beira o surreal viver em um mesmo mundo onde pessoas ainda morrem asfixiadas por gás Sarin”. A barreira idiomática desaparece com o sobe som do pai dos gêmeos exprimindo em sírio sua dor. A história do poder na Síria, descrita de forma pedagógica, relaciona a dor daquele pai ao modo de governar do líder sírio. Imagens do cotidiano da guerra, considerada pelo cronista como a "mais cruel deste século", mostram a falta de civilidade no planeta e aproxima espectadores do drama do pai sírio, em um triste bazar global. (THOMÉ; REIS; MIRANDA, 2017, p. 9).
\end{abstract}

Assim, no estudo dos deslizamentos das narrativas e nas potencialidades de links entre elas, em um sistema transmidiático, é preciso considerar as mudanças e o potencial de cada gênero textual em cada meio ou plataforma, para se entender de que forma tais narrativas estão, de fato, agregando níveis de experiência ao conteúdo jornalístico e de que forma o jornalismo está também passando por mudanças de linguagem e apropriação de estratégias da linguagem da crônica para contar as histórias nesse novo contexto.

\section{NARRATIVA ANCORADA NO JORNALISMO}

Para efeitos do que se pretende aqui, defende-se, como premissa, que crônica e conto não estão ligados somente à literatura. Quando os dois gêneros ganham caráter informativo, o jornalismo passa a ser o ponto principal, com a perspectiva da reportagem, seja ela próxima do conto ou da crônica. E a multiplicidade de veículos é o fator que destaca o caráter multimidiático - e transmidiático - da narrativa jornalística contemporânea, em que cada veículo contribui com o que tem de melhor para a construção de um todo inteligível e organizado de veicular conteúdo. Desse modo, pensa-se numa estrutura geral para um tipo de jornalismo transmídia. 


\section{Linguagens - Revista de Letras, Artes e Comunicação - ISSN 1981-9943 \\ Blumenau, v. 14, n. 1, p. 093-111, jan./abr. 2020 \\ DOI: http://dx.doi.org/10.7867/1981-9943.2020v14n1p093-11}

É necessário destacar aqui a ideia de que se trata de um dentre muitos tipos possíveis de jornalismo na contemporaneidade.

Há, então, a possibilidade de uma configuração em que conto ou crônica sejam as bases, a gênesis, de uma narrativa jornalística que se classifica transmidiática, dentro de um mesmo tipo de mídia. O que se dá por se considerar o conto uma estrutura que pode ser vista como uma unidade autônoma, ao mesmo tempo que os autores citados acima ressaltam sua ligação com a reportagem. Desse modo, um conjunto de reportagens que se comporte como vários contos pode ser considerado uma boa base para a narrativa transmidiática.

Pode-se pensar em questões mais práticas que indiquem o uso desse tipo de jornalismo transmidiático. Se as reportagens-conto ou crônica formarem algo que se assemelhe a um mesmo universo temático, isso facilita o entendimento deste tipo de formato. Cada reportagem contribuiria para a formação de um todo organizado como algo maior e mais abrangente.

A utilização de reportagens-conto ou crônica indica também algumas questões: uma, seguindo a linha de raciocínio de Sodré e Ferrari, que reforça a ideia da reportagem como algo muito aproximado do conto e da crônica e, outra, filiada à crítica literária, da semelhança dos dois gêneros em alguns aspectos. Cabe completar destacando a facilidade de modulação desse tipo de conteúdo em blocos independentes, mas que podem ter relações entre si.

Não sendo um material multimídia, por ser veiculado apenas num único veículo e utilizando apenas características do jornalismo impresso, pode-se levar em consideração alguns números de revistas, como, por exemplo, a Realidade, de janeiro de 1967, que trata da questão da mulher como ponto principal de toda a publicação. Por ser temática, a revista se constitui de matérias relacionadas entre si. Isso levaria a um princípio de organização próximo ao que a transmídia exige. As várias reportagens podem ser vistas como a construção de um todo, que é o próprio retrato da mulher daquela época no Brasil. No entanto, há a possibilidade de se pensar numa estrutura que leve em conta ainda a multiplicidade de meios para dar conta dessas reportagens, o que levaria efetivamente a se pensar em jornalismo transmidiático em um ambiente multimidiático, como vem sendo classificado pelos pesquisadores ligados ao grupo do professor João Canavilhas, na Universidade da Beira Interior (UBI), de Portugal.

Assim, num jornalismo que se queira transmídia, a reportagem deve ser o centro e não a notícia. Há ainda o aspecto de que, num espaço de reportagem, não há tanto o interesse na instantaneidade, ou seja, a matéria não tem que ser necessariamente "quente" ou a também chamada hard news. Deve-se levar em conta um tempo maior para a própria produção dos 


\section{Linguagens - Revista de Letras, Artes e Comunicação - ISSN 1981-9943 \\ Blumenau, v. 14, n. 1, p. 093-111, jan./abr. 2020 \\ DOI: http://dx.doi.org/10.7867/1981-9943.2020v14n1p093-11}

conteúdos que comporão as reportagens transmídia. Nesse sentido, deve-se pensar que o jornalismo não é somente literário, mas que esse tipo de reportagem pode levar em conta aspectos da literatura em sua construção e também que haverá espaço para se construir reportagens que se relacionem entre si. Desse modo, haveria enriquecimento de linguagem e abertura para novas experiências jornalísticas.

Os aspectos mais relevantes de tudo o que foi levantado até agora apontam para uma estrutura que requer muito mais atenção por parte de quem produz a reportagem e também indica uma maior liberdade de leitura por parte de quem está do outro lado do sistema. Ao mesmo tempo, há uma reconfiguração em marcha, que indica uma maior horizontalidade no processo comunicacional e que dá margem para que receptor e emissor troquem de papéis e tenham maior espaço de contato entre si. Isso tem sido também um fator determinante na produção jornalística atual. Se o emissor não é mais o único a se pronunciar durante esse processo, há que se pensar no espaço do antigo leitor, agora com mais voz e com mais possibilidades de se expressar.

No entanto, não é preciso fazer uma pesquisa esmiuçada para se perceber também que esse mesmo leitor não é sempre aquele que tem algo a dizer e que seus comentários e outros modos de participação podem se mostrar irrelevantes ou pouco produtivos, caso se pense apenas em um espaço para uma opinião dada sem fundamento e baseada em suposições ou posturas arraigadas de pensamento, que não levem a posição do outro em consideração. $\mathrm{O}$ fenômeno das redes sociais parece descrever bem este aspecto, em que o comentário, em sua maioria, não leva em conta o outro, mas muito mais anexa o que reforça aquilo que já foi dito e em que se acredita de antemão, sem qualquer postura crítica e chance de debate ou de discordância.

Desse modo, entende-se a dificuldade hoje em se ter um jornalismo que se coloque como tal. Em face do que já foi visto aqui, não há nenhuma preocupação maior em se ter um cuidado com o que se escreve hoje numa rede social. Daí se pensar também que, nos espaços propriamente jornalísticos, mesmo na Internet, os comentários dos leitores podem ter os mesmos aspectos de opiniões pouco embasadas e a dificuldade em fazer qualquer tipo de análise mais aprofundada e que leve em conta a possibilidade de discordância.

Ou seja, a gênesis da narrativa transmídia não se ancora na possibilidade de comentário instantâneo e compartilhamento facilitado, mas, sim, na textualidade que, intertextual, constrói narrativas complexas quando relacionadas a histórias isoladas. É o que se observa, por exemplo, nos conjuntos de contos, como os de Borges, e de crônicas, como as veiculadas pelo telejornal J10, da TV a cabo Globonews. 


\section{Linguagens - Revista de Letras, Artes e Comunicação - ISSN 1981-9943 \\ Blumenau, v. 14, n. 1, p. 093-111, jan./abr. 2020 \\ DOI: http://dx.doi.org/10.7867/1981-9943.2020v14n1p093-11}

\section{CONSIDERAÇÕES FINAIS}

O investimento em reportagens deveria ser contemporaneamente repensado no país para que a própria ideia de jornalismo transmídia se consolidasse na mídia nacional. Sem a reportagem, dificilmente se tem tal processo narrativo mais complexo. A notícia factual não se presta a este tipo de organização, já que é mais rápida e superficial, não havendo muito interesse em criar links para outros conteúdos, barrando fruições. Há que se falar ainda do pouco tempo e das redações enxutas para se investir num modelo multimídia e transmídia.

A aproximação com a literatura pode ser uma das chaves para que se tenha uma maior diversidade de material e também uma possibilidade de se trabalhar melhor as linguagens, respeitando as diferenças entre os veículos utilizados, mas também buscando novas formas de organização das reportagens criadas. Nesse aspecto, a crônica e o conto parecem ser dois gêneros textuais que devem ser levados em conta, já que têm pontos em comum com o jornalismo e são construções bem afeitas ao modelo transmidiático de se organizar o material.

Por terem a possibilidade de serem autônomas, mas também de se relacionarem entre si, reportagens-conto ou reportagens-crônica podem servir como parâmetros de estudo e também como motivadoras para a criação de espaços jornalísticos transmidiáticos.

A responsabilidade do jornalista é maior agora, apesar de se falar muito do jornalismo em crise e na maior participação do cidadão comum na produção de notícias. Talvez esteja aí uma das chaves que não são tratadas convenientemente. A informação pode ser dada até por um leitor, mas a análise, o aprofundamento, a composição da reportagem é feita por um jornalista com papel certificador. Isso não é para qualquer pessoa e nem para amadores. Mesmo que se pense no jornalista como aquele que vai validar as reportagens ditas merecedoras de crédito em função de uma avalanche de notícias falsas distribuídas todos os dias ao redor do mundo, ainda assim, não há quem tome o espaço daquele que apura, seleciona, organiza, redige e publica uma reportagem.

Ainda que se fale atualmente de robôs para produzirem material jornalístico, o que se terá são notícias produzidas em série. O olhar, a percepção e o texto do jornalista, do repórter, na produção das grandes reportagens, parecem ainda pertencer àqueles que têm um preparo para isso e que sabem que não estão fazendo um trabalho repetitivo de dar as mesmas notícias todos os dias, mas buscar, muitas vezes no mais comum, aquilo que merece ser destacado e observado com um outro tipo de sensibilidade. 


\section{Linguagens - Revista de Letras, Artes e Comunicação - ISSN 1981-9943 \\ Blumenau, v. 14, n. 1, p. 093-111, jan./abr. 2020 \\ DOI: http://dx.doi.org/10.7867/1981-9943.2020v14n1p093-11}

Está portanto, no exercício do jornalismo, da escrita, edição, vocalização e captação de imagens e nos gêneros textuais conto e crônica a chave inicial do incensado jornalismo transmídia.

\section{REFERÊNCIAS}

BIAL, P. Crônica: neste país injusto, o medo não é distribuído em iguais porções. Fantástico, 24 set. 2017. Disponível em: http://g1.globo.com/fantastico/noticia/2017/09/cronica-nestepais-injusto-o-medo-nao-e-distribuido-em-iguais-porcoes.html. Acesso em: 15 fev. 2018

CANAVILHAS, J. Jornalismo Transmídia: um desafio ao velho ecossistema midiático. In: RENÓ et al. Periodismo transmídia: miradas múltiples. Barcelona: UOC, 2014.

CANDIDO, A. A vida ao rés do chão. In.: Para gostar de ler: crônicas. São Paulo: Ática, 1980. Vol. 5.

COSSON, R. Romance-reportagem: o gênero. São Paulo: Ática, 2001.

COUTINHO, A. A literatura no Brasil. 2. ed. Rio de Janeiro: Sul Americana, 1971.

DALL'AGNESE, C. T. W.; BARICHELLO, E. M. R. Narrativa jornalística transmídia: discussões em busca de uma definição. In: XIX CONGRESSO DE CIÊNCIAS DA COMUNICAÇÃO NA REGIÃO SUL. Anais do... Cascavel: Intercom, 2018. Disponível em: http://portalintercom.org.br/anais/sul2018/resumos/R60-1618-1.pdf. Acesso em: 3 jan. 2019.

FIGUEIREDO, V. L. F. Narrativas migrantes: literatura, roteiro e cinema. Rio de Janeiro: PUC-Rio: 7 Letras, 2010.

FUHRMANN, L. "Outras noites no cais”. Revista Brasileiros. 2008.

GENETTE, G. Palimpsestes. Paris: Seuil, 1982.

ISER, W. O ato de leitura: uma teoria do efeito estético. Tradução de Johannes Krestchemer. São Paulo: 34, 1996.

JENKINS, H. Cultura da convergência. Tradução de Susana Alexandria. 2 ed. São Paulo: Aleph, 2009.

LOPES, L. Conto-reportagem: Jornalismo, literatura e indústria cultural. Via Atlântica, n. 34, p. 211-226, 21 dez. 2018.

MOTTA, L. G. Análise crítica da narrativa. Brasília: Universidade de Brasília, 2013.

PERNISA JÚNIOR, C. Jornalismo Transmidiático ou Multimídia? Revista Interin. v. 10, n. 2, 2010. Disponível em: http://interin.utp.br/index.php/vol10/article/view/18. Acesso em: 15 jul. 2011. 
PERNISA JÚNIOR, C. A mônada aberta nas narrativas contemporâneas: uma investigação. In: IV SIMPÓSIO NACIONAL ABCIBER - ASSOCIAÇÃO BRASILEIRA DE PESQUISADORES EM CIBERCULTURA. Anais do... Rio de Janeiro, RJ, 1, 2 e 3 de novembro de 2010.

MEYER, M. Folhetim: uma história. São Paulo: Companhia das Letras, 1996.

REALIDADE. São Paulo: Abril. Janeiro, 1967. Reimpressão.

REIS, M. A. O subúrbio feito letra; o cotidiano da periferia em crônicas ácidas e Carnavalizadas. 2015. 233 f. Tese (doutorado) - Universidade Federal do Rio de Janeiro, Programa de Pós-Graduação em Ciência da Literatura, Rio de Janeiro, 2015.

Arquitetura da informação. Rio de Janeiro: SESES, 2018.

REIS, M. A; THOMÉ, C. A. 'Videoteratura' - uma proposta de análise do cronismo na televisão. Linguagens - Revista de Letras, Artes e Comunicação, Blumenau, v. 11, n. 3, p. 564-585, set./dez. 2017.

RENÓ, D.; RENÓ, L. Linguagens e interfaces para o jornalismo transmídia. In:

CANAVILHAS, J. (Org.). Notícias em mobilidade: jornalismo na era dos dispositivos móveis. Covilhã, UBI, LabCom, 2013.

RIBEIRO, J. H.; MARÃO, J. C. Realidade re-vista. Santos, SP: Realejo, 2010.

SODRÉ, Muniz. A narração do fato: notas para uma teoria do acontecimento. Petrópolis, RJ: Vozes, 2009.

SODRÉ, M; FERRARI, M. H. Técnica de reportagem: notas sobre a narrativa jornalística. São Paulo: Summus, 1986.

SOSTER, D. de A. Dialogia e atorização: características do jornalismo midiatizado. In: $11^{\circ}$ ENCONTRO NACIONAL DOS PESQUISADORES DE JORNALISMO. Anais do... SBPJor. Brasília, 2013.

THOMÉ, C. de A. Literatura de ouvido: crônicas do cotidiano pelas ondas do rádio. Curitiba: Appris, 2015.

THOMÉ, C. A., REIS, M. A., MIRANDA, P. Virtualidade no cronismo do Jornal das Dez da GloboNews. In: II CONGRESSO INTERNACIONAL SOBRE COMPETÊNCIA MIDIÁTICA - UFJF. Anais do... Juiz de Fora, 23 a 25 de outubro de 2017. 